\title{
Intellectual Property Rights Dispute Resolution: Commercial Court Review
}

\author{
Djumadi \\ Law Faculty, Lambung Mangkurat UniversityJl. Brigjen H.Hasan Basri, Banjarmasin, Kalimantan Selatan, \\ Indonesia
}

\begin{abstract}
Nowadays, the law on bankrupty only ordered the authority to Commercial Court to accept the bankrupty petition. In the future, existence and performance of Commercial Court will face a variety of problems and challenges by various types of procedural law with different legal system background so it takes a special skill for the judges and institutions. In the development of Intellectual Property Rights dispute resolution, its authority become an absolute authority of Commercial Court. Dispute resolution process in Intellectual Property Rights field has special characteristic and special needs in Procedural Law, skills, and knowledge for judges and clerks who handle it. Itcan be suggested the need for judges who mastering the law on Intellectual Property Rights, criminal procedure, and the institution itself to dispute Intellectual Property Rights in the future.
\end{abstract}

Keywords: Authority, Commercial Court,Dispute Resolution, Intellectual Property Rights

\section{INTRODUCTION}

A system that can motivating technology is needed to enhance the technological development. The system needed such as human form of intelectual creation namely innovation because innovation is creation of human resources that become an essential key for the nation improvement. The innovation in Intellectual Property Rights could be filtered into an invention if potentially as an novelty, can be applied in the industry, and has an economical value so can be requested a protection through the patent system.

Conflict of interest of both sides in a community environment such as the dispute between workers and the company in a work relationship that working as a researcher and inventor who produce the invention that can be applied in industrial field and economic value. Therelationship between labour and the company can be two components are mutually complementary in an industrial process and in that interlocking position sometimes would lead to diferent interst.

Conflict interest between the two sides often cause disharmony that will affect directly and indirictly such as productivity and could affect the public interest even lead to public peace disruption if not resolved early. It could disturbing a State interest.Characteristic in Intellectual Property Rights dispute as one consequence of wealth object (property) provides authority for the owner (either as inventors, creators, designers and others) to determine who may get benefit from their intellectual creations. Basicly, there are assuming that right, liability (obligation) and privileges (preveledge) on Intellectual Property Rights is absolute and universal. According to Sudikno Mertokusumo, absolute competence or authority of judicial institution is the authority of judicial institution to check particular case type that absolutely can not be examined by other courts, both in the same courts (District Courts, High Courts, and Supreme Courts) as in other court jurisdictions (District Courts, Religious Courts). ${ }^{1}$

In the dispute resolutions there are differences on the jurisdiction in which the lawsuit is done. In principle, the applicable procedural law stated that primary jurisdiction is a place where the Defendent is. The provision found in Herziene Indonesisce Reglement (HIR). On the other hand, the Industrial Relations Court filling process as specified in Article 81 of Law Number 2 of 2004 there are characteristic of relative competency namely lawsuit that filed to Industrial Relations Court in District Court whose jurisdiction covers the place of workers/labours working, not specified the worker/labour as defendant or plaintiff.

The existence of Commercial Court as a legal means to settle debts before 1998, concerning Bankruptcy arranged in Faillisement Verordening Stbl. 1905 Number 217 jo Stbl, 1996 Number 348. But since 1998 regarding Bankcruptcy for the first time regulated in Lieu of Law Number 1 of 1998 on Bankcruptcy then designated by Law Number 4 of 1998 then updated by Law Number 37 of 2004 on Bankruptcy and Suspension of Payment Debt.

${ }^{1}$ Mertokusumo, S. (1999), Hukum Acara Perdata Indonesia, Yogyakarta, Liberty, pg. 63 
Based on Government Regulation in Lieu of Law Number 1 of 1998 stated that Commercial Court Presence established and revised by Law Number 37 of 2004. However, in the above-mentioned laws does not regulate the absolute authority of the Commercial Court to receive, check and determine Intellectual Property Rights disputes.

Subsequent development, by the enactment of Law Number 31 of 2000 on Industrial Design, Law Number 32 of 2000 on Integrated Circuit Layout Design, Law Number 14 of 2001 on Patents, Law Number 15 of 2001 on Marks (Brands) and Law Number 28 of 2014 on Copyright so settlement of Intellectual Property Rights disputes to receive, examine and decide that dispute be under absolute authority of Commercial Court.

\section{ANALYSIS AND DISCUSSION}

\section{Commercial Court in the Settlement of Intellectual Property Rights Disputes}

Starting from the existence of provisions regulating bankruptcy namely Faillessementverordening (S.1905-217) become forerunner of the bankruptcy rules in Indonesia. That regulations made in Dutch Colonial Period, then on May 1, 1906 the Insolvency Regulation (Faillessementverordening) Staatsblad of 1905 Number 217 jo Staatblaad of 1906 Number 348 which is applied on November 1, 1906. Firsly, this regulation apply for the Europeans in Indies.

In 1997 occurs economic crisis in Indonesia that caused inflasion, declining rupiah againts to US dollar value from 2,500 Rupiah to 17,000 Rupiah to US \$ 1. This condition resulted in debts of Indonesian entrepreneurs in foreign currency especially againts the foreign creditors become outstanding swollen. At that time, monetory turnoil had a huge impact in the business community's ability to meet payment obligation while the existence of Faillessementverordening as a juridicial basis is not very reliable because the slow process and uncertain success. International Monetary Fund (IMF) as a creditor to Indonesia Govermence argues that efforts to overcome the financial crisis in Indonesia can not be separated from the necessity of of foreign debt settlement and bank loan resolution efforts. Such efforts include the reform of bankruptcy law in Indonesia done in various ways such as provide expertise in bankruptcy areas, training and socialization. ${ }^{2}$

A dispute settlement mechanism is needed to resolve a dispute that happened because everyone has each interests and needs. Komar Kantaatmaja as submitted by Faisal Salam, broadly classify the disputes settlement within three (3) categories, namely:

1. Disputes settlement by using negotiations, either direct negotiation or with the third inclusion.

2. Disputes settlement by using litigation, both nationally and internationally, and

3. Disputes settlement by using arbitration, both ad-hoc and the institutions.

At first, the Bankruptcy Law just ordered one Commercial Court which is place surrounding Central Jakarta District Court. During the Commercial Court has not been established in other regions of Indonesia then the court has a relative authority to accept a bankruptcy petition on the debtor in all regions of Indonesia.Based on Presidential Decree Number 97 of 1999, the Government established the Commercial Court on five other District Court namely the Ujung Pandang District Court, Medan District Court, Surabaya District Court, and Semarang District Court. By establishing that five Commercial Court then the division of jurisdictions relative to those submitted to the Commercial Court not only become relative authority of the Central Jakarta Commercial Court, but could turn into relative authority of fifth Commercial Court.Furthermore, the provisions of Article 280 (2) Bankruptcy Law is quite clear outlines that in addition to examine and decide on the bankruptcy declaration request and debt paymentssuspension, then the Commercial Court also authorized to examine and judge other cases in commerce field are decided by government regulation.Developments associated with the absolute authority expansion of Commercial Court, today has touched the authority to examine and decide Intellectual Property Rights disputes and the trade secret disputes remain the absolute authority ofDistrict Court. ${ }^{3}$ In the laws governing the settlement of Intellectual Property Rights disputes, there are special Procedural Law in Intellectual Property Rights disputes, coupled with the establishment of procedures that are lex specialist of ordinary civil procedure that had been used on a commercial court in bankruptcy proceedings (Civil Procedural Law / HIR and Rbg).

\section{Reviewing the Commercial CourtAuthority on Intellectual Property Rights Disputes Settlement}

Besides the disputes on Trade Secret that examined on the Law Number 30 of 2000 in Trade Secret still become an absolute authority of District Court. Concerning the law provisions governing other Intellectual Property

\footnotetext{
${ }^{2}$ Holder, W.E. (2000), Indonesian Bankrupty Reform: The IMF Approach, (NSW;mDesert Pea Press), pg. 44

${ }^{3}$ Salam, F. (2009). PenyelesaianPerselisihanPerburuhan Industrial di Indonesia, Bandung: MandarMaju,
} pg. 233. 
Rights disputes settlement become an absolute competence.The statutory provisions governing the authority of Commercial Court to receive, examine, decide and resolve disputes in the field of Intellectual Property Rights obiter:

a) Article 28 of Law Number 31 on Industrial Designs,

b) Article 30 of Law Number 32 of 2000 on Layout Designs of Integrated Circuits,

c) Articles 10, 11 and 12 of Law Number 14 of 2001 on Patents,

d) Article 76 paragraph (2), 79 and 80 of Law Number 15 of 2001 on Marks and

e) Article 95 paragraph (2) and (3) of Law Number 28 of 2014 on Copyright

The authority of the Commercial Court in receiving, inspecting and deciding of Intellectual Property Rights disputes coupled with the establishment of procedures that are lex specialist from the usual procedure civil procedure and the judicial procedure in the Commercial Court in the bankruptcy process is known so far. Law governing Intellectual Property Rights described a new judicial procedure itself, for example, the timing of the specific case. But in contrast with the bankruptcy petition, as well as ordinary civil cases plus the provisions regulating the meantime Determination by the Court.Specificity of the procedure in Intellectual Property Rights disputesalso found in the provisional decision from the Court. The provision which is similar to the guarantee which allows the execution of a binding stipulation to third party before obtaining permanent decision even before the dispute or is filed lawsuit to the Commercial Court.

The characteristics that set of CourtDetermination Decision among other requested and implemented before the dispute submitted as a claim to the Court. While the foreclosure requested after the dispute filed a lawsuit to the Court. Other characteristics are the Intellectual Property Rights as an asset that can be used as a collateral.

\section{Disputes Resolution Absolute Authority between Worker as an Inventor and Company}

Concerning a dispute between workers or labour and employer with working facilities while doing research to produce invention they bonded in labour relation. The issue has been regulated in Law Number 14 of 2001 on Patent. In the provision of Article 12 paragraph (5) of Law Number 14 of 2001 on Patent stated that:In that provision if there is no conformity regarding the calculation and determination procedure of remunation, article 12 paragraph (5) states that is a Commercial Court authority to decide.

The provisions as an effort to anticipate if the workers or labour produce invention either bounded or not bounded in working relationship even the working relationship does not ask them to produce invention, as long as using data and/or facilities that available in the company on the job. ${ }^{4}$ In the event when they did so, if there is a dispute between employees/workers with employers as data providers and working facilities sothe invention that workers produce become a question about competence/absolute authority, which court is authorized to receive, examine and decide disputes the right to remuneration from the patent royalties.

On the other side, the existence of the Industrial Relations Court is in the District Court which is having jurisdiction covers of workers/laborers. In additiondetermined on absolute authority in receiving, inspecting, decide and settle on the right disputes between workers and companies.

Furthermore, in accordance with the provisions of Article 2 of Law Number 2 of 2004 specifies that Industrial relations disputes types include:

a. Disputes over rights;

b. Conflict of interests;

c. Over termination of employment Disputes, and

d. Disputes between trade unions/labor unions within one company.

Furthermore on Article 56 provides that:

Industrial Relations Court has a duty and authority to examine and decide:

a. In the first instance on disputes over rights;

b. In the first and last of the conflict of interests;

c. In the first instance regarding the termination of employment, and

d. On the first level and last regarding disputes between unions/labor unions in one company.

What is meant by disputes over rights is a dispute over workers' basic rights that have been defined in the employment agreement, company regulations, collective labor agreements, or legislation.Meanwhile, according to the provisions of Article 1 paragraph 2, which referred to rights dispute is a dispute arising from the non-fulfillment of rights because of differences in the application and interpretation of the provisions of legislation, employment agreements, company regulations or collective agreements.

${ }^{4}$ Soepomo, I. (1975). HukumPerburuhanbidangHubunganKerja, Jakarta: Djambatan, pg. 172 
Disputes over rights (rechtsgeschil) is a dispute arising from one of the parties on the employment agreement or labor agreement does not meet the contents of the agreement or violation of the law. ${ }^{5}$ Disputes over rights is also referred as normative disputes, ie disputes concerning matters governed or have legal basis. Notwithstanding, or has legal basis, it is not uncommon for the break. Theoffending party sometimes assume the other party (workers/employees) may be violated by all sorts of reasons, the arguments in spite of themselves, so that the worker injured his right (it could be vice versa).

Based on the above understanding, it disputes is an incident in which a party's right which has been determined by legislation, employment agreements, company regulations or collective agreements are not acquired. Therefore, the party whose rights have been infringed is entitled to claim against the adverse party by reason of the strife rights.Furthermore, according to the legislation in force, the dispute regarding the basic rights set forth in the employment agreement, it can be seen from the legislation governing patents, namely Article 12, paragraph (b) of Law Number 14 of 2001 on Patents.

In the case of patent disputes, as well as other disputes in Intellectual Property Rights dispute, the dispute to be the absolute competence of the Commercial Court that has the authority to examine and decide. Where the presence of judicial institutions namely the Commercial Court and the Court of Industrial Relations, both of which are special courts set up and its presence in the District Court. On the other side, the existence of the Industrial Relations Court is in the District Court having jurisdiction covers the workers/laborers also determined on absolute authority in receiving, inspecting, decide and settle on the right disputes between workers and companies ${ }^{6}$. What is meant by disputes over rights is a dispute over workers' basic rights that have been defined in the employment agreement, company regulations, collective labor agreements, or legislation.

Based on the above understanding, it disputes is an incident in which a party's right which has been determined by legislation, employment agreements, company regulations or collective agreements are not acquired. Therefore, the party whose rights have been infringed is entitled to claim against the adverse party by reason of the strife rights.Furthermore, according to the legislation in force, the dispute regarding the basic rights set forth in the employment agreement, it can be seen from the legislation governing patents, namely Article 12, paragraph (b) of Law Number 14 of 2001 on Patents.

In the case of patent disputes, as well as other disputes in Intellectual Property Rights dispute, the dispute to be the absolute competence of the Commercial Court that has the authority to examine and decide. ${ }^{10}$ Where the presence of judicial institutions namely the Commercial Court and the Court of Industrial Relations, both of which are special courts set up and its presence in the District Court.

\section{Characteristics of Intellectual Property Rights Dispute Resolution}

In the examination process of Intellectual Property Rights disputes, acknowledged there are specific characteristics that may take a longer examination. That way, if it is not considered from an early stage, the Commercial Court will be working with various types of procedural law in the future. ${ }^{7}$ In practice, judges in Indonesia in general have been accustomed to using HIR and Rbg (including Rv) in carrying out the procedural law in court. Even the procedural law that is used as a guideline in the Commercial Court unless otherwise stipulated in this law then the procedural law applicable is the Civil Procedural Law.

In the settlement of disputes in intellectual property rights field, it is not possible Commercial Court Judges only based on the Civil Procedure Law that had been valid because the existing problems in the intellectuals property rights field can not only be guided by the Civil Procedure Law, for example concerning the provision of Determination While the Court (PSP) and Intellectual Property Rights as a means of collateral.Thus, legislation governing Procedural Law is needed. The Court has absolute authority specialized in intellectual property rights field, as well as competence judges to receive, examine and decide the dispute must master the substance of Intellectual Property Rights issue.There is a thing that should be noted, that the Act governing intellectual property rights if the law is silent on the independence of the event procedures should refers.

In contrast with the provisions of the laws governing bankruptcy, which clearly states that if it is not specifically regulated in the Law on Bankruptcy so the law applicable is the law of civil procedure. Other specific problems is different from the Bankruptcy problem that under Article 284 about Bankruptcy Act which is the Procedural Law still possible to do renvoi procedure to the provisions of the Public Procedural Law.

\footnotetext{
${ }^{5}$ Ugo and Pujiyo, (2012). Hukum Acara, PenyelesaianPerselisihanHubunganKerja, Tata Cara dan Proses PenyelesaianSengketaPerburuhan, Jakarta: SinarGrafika, pages 27-28.

${ }^{6}$ Suyudi, A. et al., (2003),Kepailitan di NegeriPailit (Analisa HukumKepailitan Indonesia), First edition. Jakarta: Pusat StudiHukum\&Kebijakan Indonesia.

${ }^{7}$ Ibid. 
While disputes in the Intellectual Property Rights rights fields under procedural law in particular did not regulate where procedural law should reference when in fact the law does not regulate matters that may occur in the practice of the trial.No reference of this rule could cause a lot of trouble and confusion in dispute resolution practices in Intellectual Property Rights field.Other specific problems is different from the Bankcrupty problem that under Article 284 on Bankruptcy Act which is that procedural law is still possible to do renvoi procedure to the provisions of the Public Procedural Law.

While disputes in the Intellectual Property Rights rights fields under procedural law in particular did not regulate where procedural law should reference when in fact the law does not regulate matters that may occur in the practice of the trial. No reference of this rule could cause a lot of trouble and confusion in dispute resolution practices in Intellectual Property Rights field.Injunctions legal institutions, as legal sources of Civil Procedure Law namely HIR, Rbg and/or Rv which is generally filed by the Plaintiff the essential main requirement should be submitted to the District Court. There is the principle of hearing both sides and there is a remedy.

However, with the provision of Article 14 paragraph (2) in conjunction with Article 117 paragraph (2) of Law Number 14 of 2001 is not applicable to the Lex Specialty principle derogate lex generalis. In case the working relationship dispute between workers as researchers as well as inventors with employers who are bound in employment agreements and resulted an invention which has high economic value, new technology and can be applied to the industry. Are disputes of rights become an absolute of Industrial Relations Court namely the dispute about the rights that should be obtained in the employment relationship which is the right of the worker as an inventor as specified in Article 2 letter a jo Article 56 of Law Number 2 of 2004.

In the legislation in Intellectual property rights field described a new judicial procedure itself, for example about the specific time limitations dispute settlement and Court Nonpermanent Determination instrument, which are instruments similar to the entry into force of the instrument for sequestration which allows the execution of a binding determination to a third party prior to obtaining a permanent decision. ${ }^{8}$

\section{CONCLUSION}

The ideas and structure of the Indonesian Commercial Court it can be concluded that the establishment of Commercial Court at Central Jakarta District Court was not intended to stop the Commercial Court only as a "court for the bankruptcy case" mere. There appears to be a long term plan to use the Commercial Court as a vehicle to improve the performance of the judiciary as a demands of the economy world as a whole. Thus, it is recognized that in the process of dispute resolution in intellectual property rights field there are specific characteristics that allow the examination takes longer, specialized skills and knowledge for judges and clerks who handle it. It needs a legal framework that specifies that intellectual property rights can be used as collateral guarantee and elaborated in the form of implementing regulations governing the appraisal, public accountants, rating agencies, brand exchanges, and institutions resolution dispute, for example, about the existence of a special court that has authority to examine and determine Intellectual Property Rights disputes. Regarding the absolute authority in settling disputes between the rights of the employee/worker/ Civil Servants as Inventor bound employment relationship with the Company/Institution/Agency as employer and working facilities is still a difference opinion on the Court which has absolute authority over the dispute, which is authorized to examine and determine/set.

In the future existence and performance of the Commercial Court will face various problems and challenges with various types of different legal systems backgrounds so it takes a special skill for judges and institutions. Fore the need for the judge who controlled the Procedural Law in Intellectual Property Rights dispute and the Court specifically authorized to examine and determine Intellectual Property Rights disputes.

\footnotetext{
${ }^{8}$ Hutagalung, S.M. (2012). PraktikPeradilanPerdatadanAlternatifPenyelesaianSengketa, Jakarta: SinarGrafika, pg 404 